about such robes, but without gaining any information. Dr. W. T. Hornaday told me he had heard of them, but had never seen one.

My cousin, Miss Bates, was in the Canadian Rockies in 1906, and the guide who took her on some of her trips showed her a photograph of his family, and called attention to a skin on which the group were seated, saying that it was a silk buffalo, killed on the Canadian prairies. The guide's father was an early settler in that region, and got the skin when he first came out. The guide spoke of its rarity and value, and was much surprised and interested to learn that my cousin knew about them and owned one. Both he and my uncle said that in a large herd occasionally one of these fine silk animals was found, but never more than one.

Mr. David N. Heizer of Colorado Springs informs me that in Kansas, after the civil war, the young buffalo bulls in November were said to be in the silk.

Can any of my readers give me any information about these skins? I am naturally somewhat curious to learn if there is really any truth as to the rarity and value of these fine-haired skins.--EDWARD R. WARREs, Colorado Springs, Colo.

THE CALIFORNIA GRAY WHALE ON THE COAST OF SOUTHERN CALIFORNIA

Recent writers on our Cetacea have stated that the California gray whale (Rhachianectes glaucus) is extinct on our coast and is, at this time, found only in small numbers along the coast of Japan. Some have gone so far as to state that it is twenty years since the last of the California grays appeared on the American coast. As I had considered this species one of our most common whales, when I left this part of the coast twenty-three years ago, I found it hard to reconcile these records with my own observations.

A trip to the Coronado Islands, twenty miles south of the harbor of San Diego, March 5, 1921, gave me the first, and, to date, the only chance of observing whales; and I was gratified to see two fine male California gray whales under conditions that rendered identification beyond question. These were the only whales of any species secn on the trip. They were northward bound and evidently migrating.

When I first came to the cosst of southern California, in 1887, there were still to be found many of the old time whalers who had, from the earliest history of the whale fishery, followed the "shore whaling," hunting the "fish" from shore stations with hand-irons. These men knew the several species of our Pacific whales as they will never again be known. The present generation know little of our whales, and care less; and it is hard to obtain, at this time, any reliable data.-A. W. Antrony, San Diego, Calif.

\title{
A HANDY COLLECTING CASE
}

The case for drying and carrying specimens of birds and small mammals, shown in the accompanying drawing, is the handiest and most useful case for certain field work that I have ever seen. Upon my showing it to Dr. Walter P. Taylor, of the U. S. Biological Survey, during a recent visit of his to the California Academy of Sciences, and my explaining to him its main features, he asked me to send a description of it to the Journal of Mammalogy so that others might benefit by it. 
As shown in the drawing, the case is 25 inches long by 14 inches high, and 7 inches deep, outside measurements. While these dimensions may be varied at will, they are those of a fairly large "suit case," and this size is handy to carry, to stow away in passenger coaches or automobiles, and will sling well on a pack saddle.

This case is made of some light, tough wood, $\frac{1}{2}$ inch in thickness, reinforced at the ends with angle irons or brass. The solid outer "door" of the case is of the same material as the main body of the box, but its ends are strengthened by a strip running across grain, nailed, screwed, or glued on, as is usually done in such construction.

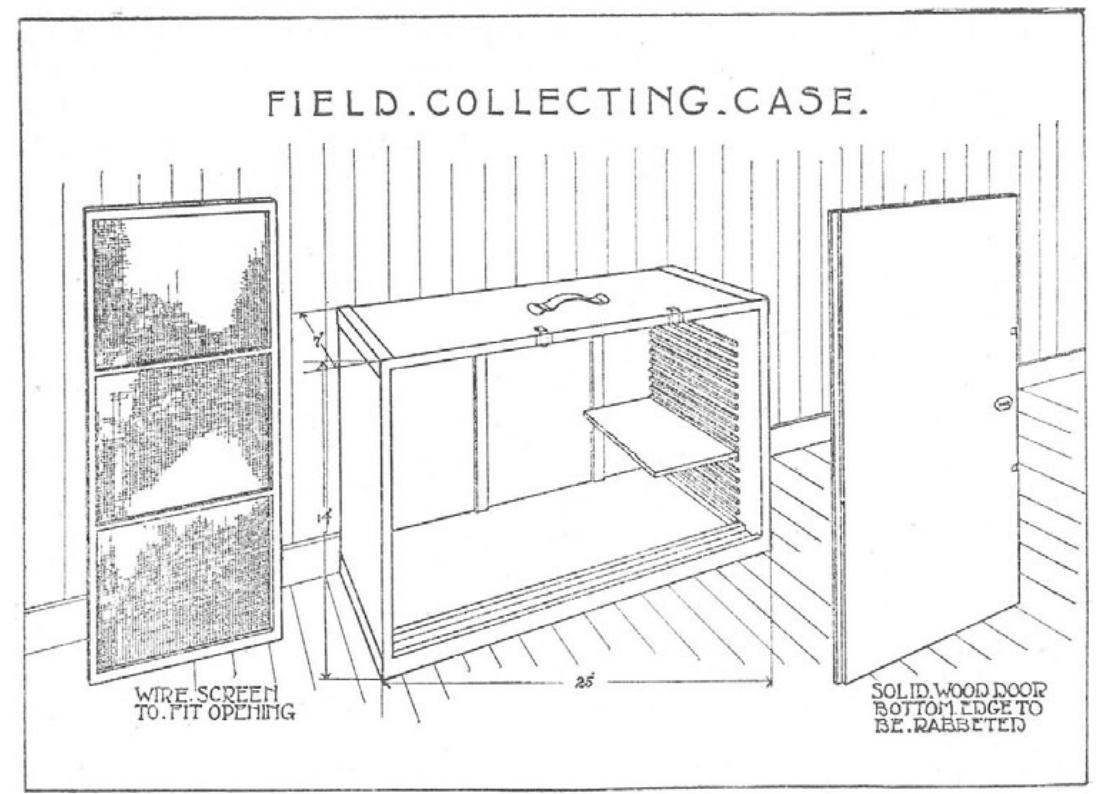

The shelves are of $\frac{x}{4}$ or ${ }_{16}^{3}$ inch wood that must be soft enough to take pins well. Five shelves to a case are ordinarily sufficient for average collecting. As shown in the cut, the eleats for the shelves do not extend quite up to the top, and when not in use for specimens the shelves can all be stowed away in the upper part, leaving the rest of the box clear for packing material and supplies, such as mouse traps, cotton, or anything not too heavy.

The cleats are short enough, and the shelves narrow enough to allow the screen door to lie between them and the outer door, so that when the latter is removed, the screen is in place to protect specimens from flies, mice, eats, etc. The frame for this wire screen should be made of tough, straight-grained wood, as it is of light construction and must stand handling in taking out and putting in place, as well as an occasional fall. 
Freshly prepared skins of birds or rodents, when properly pinned to the shelves, withstand the jolting of carrying by hand and of ordinary travel in good shape, but will not resist the attacks of the average "baggage smasher," of course.

The cut shows a couple of thin perpendicular strips in the rear of the case. These are so placed as to allow the passage of air behind the shelves for the better ventilation and more rapid drying of specimens. The wire side of the screen door must always be turned to the rear so that the frame will present something for the fingers to grasp in handling.

A lock is put on the solid door, and two pieces of metal are secured in slots so as to drop down and act as catches. When the outer door is removed for drying specimens these will also keep the screen door in place. These eatches, as shown in the cut, could be improved upon, or small flat bolts might be set in the door instead, so long as everything is flush with the surface. Some sort of a trunk handle on the top of the case, and a leather "tab" fastened with screws on the door to aid in handling it, complete the job.-Josepr Mailliard, California Academy of Sciences, San Francisco.

\section{RECENT LITERATURE}

Dixon, Joseph. Control of the Coyote in California. Berkeley, University of California Press, Bull. no. 320, College of Agriculture, pp. 379-397, 7 figs., April, 1920.

In this bulletin the author has succeeded admirably in presenting a concise and fair: statement of the economic relations of the coyote in California and the measures proposed for its control. To those who would regret the passing of the coyote, Dixon's demonstration of the fact that "a coyote is not necessarily a bad citizen" will be welcome. With prime coyote pelts selling up to $\$ 10$ and even $\$ 20$ each the fur value of the animal is not to be minimized. Add to this the beneficial activities of the coyote in destroying noxious rodents, particularly ground squirrels, and it must be conceded that the economic value of the animal is a real and not an imaginary quantity. Of course, adverse testimony is not lacking. The coyote is stated to be the most destructive carnivorous animal now existing in California, and reference is made to depredations on deer, sheep, pigs, and calves. Furthermore there is, at times, grave danger of the spread of rabies through coyotes to horses, cows, goats, dogs, cats, and other domestic animals as well as to man. Consequently control measures are essential.

The bounty system is unreservedly condemned, as being vastly expensive, productive of endless fraud, and failing to give general or permanent relief. Coyote proof fences give good results under favorable conditions. The four most effective methods of destroying coyotes are stated to be trapping, poisoning with strychnine, digging out dens containing young, and shooting. It is Dixon's opinion, on the basis of results obtained in Nevada and parts of California, that cooperation in coyote control between the State and Federal governments through the Biological Survey is much superior to the bounty system. This work, supervised by the government, is carried on upon a half-and-half basis. Experienced trappers are employed on a salary and are not permittod to accept bounties from any source. 